INMR

19,2

Received 26 April 2020

Revised 20 July 2020

15 September 2020

Accepted 4 October 2020

\section{Cross-cutting best practices for new product development (NPD) in turbulent environments: the effects of integration and co-creation}

\author{
Mateus Panizzon, Gabriel Vidor and Maria Emília Camargo \\ Graduate Program in Industrial Engineering (PPGEP), \\ University of Caxias do Sul (UCS), Bento Gonçalves, Brazil and \\ Graduate Program in Business Administration (PPGA), \\ University of Caxias do Sul (UCS), Caxias do Sul, Brazil
}

\begin{abstract}
Purpose - Continuous understanding of the best practices associated with new product development is a constant research opportunity to advance knowledge in the field, as far as changes in the business environment and the increasing turbulence level in different market segments create and reposition the importance of practices over time.

Design/methodology/approach - Based on a systematic review, the study aimed to analyze the 100 most relevant articles published in international journals on new product development (NDP), identifying new patterns on the best practices for new product development and the types of relationship involved in NPD.

Findings - Among the several practices observed in the literature, the analysis point to a larger group of studies that converge on the identification of a positive and significant relationship in integration simultaneously - between supplier, company, customers and strategic alliances and the performance of NPD. Research limitations/implications - These results support integration as a cross-cutting and structural best practice for NPD, as long as it is constituted as a capacity, mainly applied in highly turbulent environments. This approach supported the proposition of a new framework.

Practical implications - Organizations will be able to implement the proposed framework to NPD strategy in order to prioritize resources in best practices, aiming to increase the performance of new product development.

Social implications - The adoption of integration and co-creation practices for the development of new products expands the possibilities of economic and social development, based on the involvement of the actors in this network.

Originality/value - This model had not yet been proposed in the literature, filling a gap in the agenda for future studies.
\end{abstract}

Keywords Best practices, New product development, Integration, Co-creation, Digital transformation Paper type Research paper

\section{Introduction}

This study analyzes the best cross-cutting practices for successful new product development (NPD) based on a systematic literature review, in which we intend to observe new patterns related to the topic. Why is this type of analysis relevant at this moment? The growing evolution of the market imposes a greater flexibility from companies in the application of

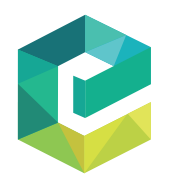

(C) Mateus Panizzon, Gabriel Vidor and Maria Emília Camargo. Published in Innovation \& Management Review. Published by Emerald Publishing Limited. This article is published under the Creative Commons Attribution (CC BY 4.0) licence. Anyone may reproduce, distribute, translate and create derivative works of this article (for both commercial and non-commercial purposes), subject to full attribution to the original publication and authors. The full terms of this licence maybe seen at http:// creativecommons.org/licences/by/4.0/legalcode.

The authors wishes to thank the anonymous reviewers and the editor of this journal, for their helpful and constructive comments on earlier versions of this article.
Innovation \& Management Review pp. 106-122 Emerald Publishing Limited 2515-8961

DOI 10.1108/INMR-04-2020-0053 Vol. 19 No. 2, 2022 
different strategies, methods and techniques that yield competitive advantage for their products (Cheng, Chen \& Tsou, 2012; Rodríguez-Pinto, Rodríguez-Escudero, \& GutiérrezCilláb, 2012), considering the intensification of globalization and connectivity.

While the quality of products increases, technological development has also been shortening distances, improving communication and reducing processing. Thus, customers have more access to a greater variety of products and services than in the past, which increases competition, differentiation and customization. Therefore, to develop a value proposition and a cost-benefit perception by aggregating differentiation factors, such as quality and innovation attributes, delivery time and connectivity, investment in new technologies for NPD is essential at the product and process level.

In this sense, the capability for identification and technological absorption, supported mainly by the level of organizational learning and available human and financial resources, becomes a determining factor for promoting competitive differentiation, based on the degree of technological differentiation. In this new scenario, it is necessary to consider that competition is no longer limited to companies. Corporate networks and supply chains are responsible for the creation of a complex business environment globally, in which companies are compelled to collaborate to create competitive differentiations and technological integration; this new dynamic, therefore, affects practices related to NPD (Flynn, Huo, \& Zhao, 2010; Koufteros, Rawski, \& Rupak, 2010).

Thus, identifying and cataloging NPD practices have been the subject and purpose of several studies over the past years (Cooper \& Kleinschmidt, 1995; Griffin, 1997; Carrizo-Moreira \& Leonidivna, 2014; Boehe, Milan, \& de Toni, 2009; O'dwyer \& Cormican, 2017). These studies aim at understanding the variables that positively influence the process. Furthermore, as far as research on NPD consolidated, meta-analysis approaches also contributed significantly to the understanding of the critical success factors of NPD and innovation in general over the last decade, such as the approaches by Montoya-Weiss and Calantone (1994), Henard and Szymanski's (2001), Chen, Damanpour, and Reilly (2010), Crossan and Apaydin (2010) and Evanschitzky, Eisend, Calantone, and Jiang (2012).

Evanschitzky et al. (2012) mentions a relevant finding in the NPD field; the author affirms that the importance of critical success factors declines over time as new theoretical approaches emerge and as these practices begin to become more known globally thanks to benchmarking. Therefore, within the NPD field, it is expected to find cycles of renewal of the practices. An important characteristic to be observed in studies on NPD practices is that they depend on and need to be contextualized and understood by considering the business segment, company size, national culture and even the level of internationalization. This is the reason why one finds in the literature a diversity of practices that positively affect the performance of NPD. Therefore, with the evolution and new configuration of the business environment, mainly due to the need for digital transformation (Zapata, Berrah, \& Tabourot, 2020), there is a need to identify the patterns of practices mapped by literature while considering the dynamics of NPD in different business segments. Therefore, considering such context and due to the theoretical gap exposed, our research identifies the main crosscutting practices associated with NPD, in addition to determining new patterns.

\section{New product development practices}

According to Buyukozkan and Feyzioglu (2004) and Zabala-Iturriagagoitia (2017), new product development can be understood as transforming a market opportunity and considerations about a product technology into a product available for sale. Thus, in order to achieve this transformation, it is necessary to integrate knowledge and activities in marketing, engineering, operations, among others; a good performance in NPD depends on the combination of resources, capacities and skills existing in the company in 
INMR

19,2

108

the form of best practices (Tai, 2017; Woschke \& Haase, 2016; Song \& Parry, 1997; Verona, 1999).

Therefore, this multidisciplinarity engenders particular characteristics of research, and it is necessary to systematize the different perspectives of analysis in this new value chain (Carrizo-Moreira \& Leonidivna, 2014), which tends to expand the inventory of practices in the literature. Therefore, academics and NPD practitioners are interested in analyzing NPD practices because identifying a practice - a technique, a method, a process or an activity - that is capable of delivering a new product more efficiently and effectively could be the difference between success and failure of the product and the company (Barczak \& Kahn, 2012). Cooper (2019) points out that, globally, approximately $40 \%$ of new products fail in the launch; thus, the constant identification and updating of NPD practices become necessary.

NPD practices are organized in a few dimensions. Barczak and Kahn (2012), for instance, conceptualize the NPD in seven different dimensions of performance according to their role in the fields of strategy, research, commercialization, process, organizational environment, organizational culture, metrics and performance measurement.

In this sense, several studies focus on the themes presented by these dimensions, among which are knowledge management (Li, Pehlken, Qian, \& Hong, 2016; Jia, Kang, \& Gao, 2016), market strategy (Chao \& Chen-Hao, 2015; Haverila, 2010), project strategy (Yang, 2012) and interorganizational strategies (Yan \& Azadegan, 2017) as success factors for NPD. From a systemic approach, Cooper (2019) revisited the successful drivers of NPD and organized NPD information in a structure with three levels. These three levels explain that NPD success is a function of the individual drivers of the project, of strategic organizational drivers of the business and of the adopted system and process drivers. This view denotes the multidimensional approach of the NPD field. Furthermore, it indicates the approach of agile methods with greater emphasis on the exchange of information between customers and suppliers seeking greater speed in comparison to the initial linear models of NPD (Figure 1).

Evanschitzky et al. (2012), when updating the meta-analysis of Henard and Szymanski (2001) based on the practices described in Figure 2, identified an important finding, which is the effect of time on NPD best practices. There is evolutionary evidence that best practices may lose their effect size over the years as they become known and the business environment changes. Furthermore, culture emerges as a key moderating factor, in which countries with greater risk aversion have better performance in NPD, and individualist countries, with a low capacity for collaboration, present a worse performance.

When comparing the most recent models, e.g. the one developed by Evanschitzky et al. (2012) based on Henard and Szymanski's (2001) and the one of Cooper (2019), one identifies a few similarities concerning NPD practices; however, at the same time, such comparison indicates a new managerial problem, namely the number of variables and the complexity of the models for NPD managers.

As resources become scarcer in companies, there is an increasing need to prioritize them, and issues about which variables are more explanatory for NPD variability turn into an opportunity for investigation. Each practice variable translates, in managerial terms, into the need for resource allocation, know-how and experience curve. Therefore, it becomes necessary to advance in the understanding of more strategic and systemic decisions about NPD, whose allocation of resources implies direct and indirect impacts on the entire system.

One of these approaches refers to the capability concept, as investigated by Zawislak, Fracasso, and Tello-Gamarra (2018): companies can obtain innovative capacity, even in different technological intensities, as long as they balance their technological, operational, managerial and transnational capabilities. This approach is especially critical in the case of Brazilian companies, which, in general, are not provided with the same level of resources as 


\begin{tabular}{|c|l|}
\hline Level & \multicolumn{1}{c|}{ Best Practices } \\
\hline \multirow{4}{*}{ Individual Drivers of NPD } & Unique superior products \\
& Market-driven products and voice-of-the-customer (VoC) built in \\
& Pre-development work - the homework \\
Sharp, early, and fact-based product definition & Iterative, spiral development - build, test, feedback, and revise \\
& The world product - a global orientation \\
& Planning and resourcing the launch \\
\hline \multirow{5}{*}{ Organizational and Strategic } & A product innovation and technology strategy for the business \\
& Focus and sharp project selection decisions - portfolio management \\
& Leveraging core competencies - synergy and familiarity \\
& Targeting attractive markets \\
& The resources in place \\
& Effective cross-functional teams \\
& The right environment - climate and culture \\
& Top management support \\
\hline \multirow{5}{*}{ Systems and Processes Drivers } & A multistage, disciplined idea-to-launch system \\
& Speed - but not at the expense of quality of execution \\
& Building agile into traditional B2B gating systems \\
& Effective ideation \\
& Quality of execution \\
\hline
\end{tabular}

Cross-cutting best practices for NPD

109

Source(s): Adapted from Cooper (2019)

\begin{tabular}{|c|c|}
\hline Dimension & Practice \\
\hline \multirow{5}{*}{ Product characteristics } & Product advantage \\
\hline & Product meets customer needs \\
\hline & Product price \\
\hline & Product technological sophistication \\
\hline & Product innovativeness \\
\hline \multirow{7}{*}{ Strategy characteristics } & Marketing synergy \\
\hline & Technological synergy \\
\hline & Order of entry \\
\hline & Dedicated human resource \\
\hline & Dedicated R\&D resources \\
\hline & Company resources \\
\hline & Strategic orientation \\
\hline \multirow{11}{*}{ Process characteristics } & Structured approach \\
\hline & Predevelopment task proficiency \\
\hline & Marketing task proficiency \\
\hline & Technological proficiency \\
\hline & Launch proficiency \\
\hline & Reduced cycle time \\
\hline & Market orientation \\
\hline & Customer input \\
\hline & Cross-functional integration \\
\hline & Cross-functional communication \\
\hline & Senior management support \\
\hline \multirow{4}{*}{ Marketplace characteristics } & Likelihood of competitive response \\
\hline & Competitive response intensity \\
\hline & Market potential \\
\hline & Environmental uncertainty \\
\hline \multirow{6}{*}{ Organizational characteristics } & Organizational climate \\
\hline & Project/organization size \\
\hline & Organizational design \\
\hline & External relations \\
\hline & Degree of centralization \\
\hline & Degree of formalization \\
\hline
\end{tabular}

Source(s): Adapted from Evanschitzky et al. (2012)

companies investigated in international and more developed scenarios. Therefore, this analysis is extended to emergent countries.

According to Evanschitzky et al. (2012), it is necessary to understand the NPD from a cultural perspective, in which the availability of resources is asymmetric not only among 
INMR

19,2

\section{0}

Figure 3.

Research procedures

Figure 4 .

Categorization structure for analysis countries but also among the different types of business segment. Even in Brazilian cases, one finds divergent findings, as in the study of De Toni, Milan, and Reginato (2011) and Tumelero, Santos, and Plonski (2012); the explanation for such mismatch is attributed to the sectors analyzed. In the latter study, intensive high-tech sectors are usually related to different kinds of relationship with universities (Costa, Porto, \& Plonski, 2010), which was not identified in the first case. These elements justify the need to evaluate NPD practices in recent articles of greater scientific relevance, identifying new transversal standards to the segment of activity.

\section{Method}

We adopted a quantitative approach to our study with exploratory features. As research strategy, we carried out a systematic review approach, in which a few patterns were identified. The Web of Science and Scopus databases were selected as data sources, considering the CAPES CAFe system. These databases were chosen for their high coverage in terms of worldwide reach, expanding the search results (Gusenbauer \& Haddaway, 2020; Meho \& Yang, 2007; Falagas, Pitsouni, Malietzis, \& Pappas, 2008). As query operator, the term "New Product Development" was applied, proceeding with the selection of articles before 2018, in English, and without restricting the area. The decision to apply such operator was related to the expansion of the range of studies, aiming at a more comprehensive identification of different types of practices. From this consultation, we selected the articles according to the following criteria (Figure 3).

The articles selected were organized in an electronic spreadsheet according to the following variables: (1) name of the article, (2) issue date, (3) researched segment, (4) practice analyzed and (5) relationship with the NPD identified based on the observation of the models and hypothesis testing. Considering that the research aim was not to provide a bibliometric analysis in which the frequency of publications by authors or journals is evaluated, such variables were not considered in our study. Thus, as the article was analyzed according to the above-mentioned stages and the variables identified, the new information was reported in the table. The final structure is shown in Figure 4; at a first level, the practice was reported, and at

\begin{tabular}{|c|l|}
\hline Step & \multicolumn{1}{c|}{ Procedure } \\
\hline 1 & $\begin{array}{l}\text { The authors classified the articles in order of relevance, thus understanding the level of citation and adherence } \\
\text { to the keyword. In this way, the articles selected are the most relevant when consulted the term "New Product } \\
\text { Development" from the classification of the relevance of the bases, which considers citations and views } \\
\text { concerning time. With this approach, there is a selection based on the level of the relative importance of the } \\
\text { selected works to the great NPD theme. }\end{array}$ \\
\hline 2 & $\begin{array}{l}\text { Based on this classification, the title and abstract were analyzed, in the sequence provided by the bases: if the } \\
\text { article expressed in the title or abstract a link to terms related to the NPD, such as "best practices/strategies", } \\
\text { "innovation", "critical factors", "NPD success", among others. The authors selected the articles for the } \\
\text { database for further identification of the NDP practices presented in the documents. }\end{array}$ \\
\hline 3 & $\begin{array}{l}\text { The aim was to identify in the author's research conclusions in terms of the positive or negative role of such } \\
\text { practices in NPD performance. }\end{array}$ \\
\hline
\end{tabular}

Source(s): Research data
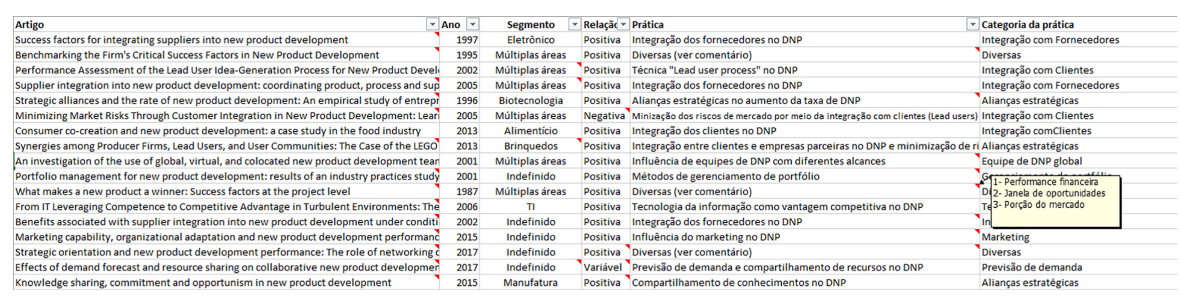

Source(s): Research data 
a second level, the practices were categorized to standardize the nomenclature. When several practices were observed, they were identified for a secondary analysis and traceability.

The data collection was conducted based on these criteria; 50 articles were allocated to the Web of Science and the other 50 to Scopus. Concerning the periodicals that publish research articles, the selected publications were published in major journals, such as Journal of Product Innovation Management, Industrial Marketing Management, Technovation, Journal of Business Research, Long Range Planning, International Journal of Technology Management, International Journal of Innovation Management, Research Technology Management, R\&D Management, among others. We emphasize one more time that the aim of our article is not to provide a bibliometric analysis in which the panorama of the area is approached; our research aim is, however, to identify new standards related to best practices by using this method. After the organization of the database, we carried out an analysis seeking to identify patterns and categories posteriori.

\section{Results and discussions}

\subsection{Categorization and analysis of the practices identified}

From the analysis of the articles, we identified the following categories related to the practices that are positively associated with NPD, as shown in Figure 5.

Table 1 presents the result of the analysis, and, considering the multifunctional nature of NPD, it is possible to observe the occurrence of several practices. Among these practices, however, there are a few patterns. The higher incidence found is in the analysis of integration practices at a horizontal level (suppliers and customers), as well as at a vertical level (strategic alliances). Therefore, three categories (i.e. $7 \%$ of the total) correspond to $30 \%$ of the articles, which indicates that the authors should focus the analysis on them.

Another relevant finding we identified (Table 2), which provides an overview of the publications over the period analyzed, is that the integration of suppliers and customers, as well as strategic alliances, are topics that have been gaining research interest overtime. There is a trend toward the emergence of some practices that have not yet been studied. Some NPD practices, such as sustainability, marketing and the role of design in the process of developing
Cross-cutting best practices for NPD

\begin{tabular}{|c|c|}
\hline Categories identified & Findings \\
\hline \multirow{4}{*}{$\begin{array}{l}\text { Strategic alliances| Patents analysis| Capturing new } \\
\text { opportunities| Integration Clients and suppliers| Design| } \\
\text { Reverse engineering| Global NPD team| } \\
\text { Multidisciplinary teams| Market strategy| Project } \\
\text { strategy| Interorganizational strategies| Management } \\
\text { tools| SPS tools| Flexibility of work environment| } \\
\text { Flexibility of management| Open innovation flow| } \\
\text { Supply of innovation| Knowledge management| Quality } \\
\text { management| Portfolio management| Product life cycle } \\
\text { management| Pre product development| Open } \\
\text { Innovation| Management Innovation| Client Integration| } \\
\text { Sector Integration| Supplier Integration| Marketing| } \\
\text { Business Network| Strategic Planning| Product } \\
\text { Platforms| Cost Forecasting| Demand Forecasting| } \\
\text { Physical and Virtual Prototypes| Social Networks| } \\
\text { Sustainability| Information Technology| Outsourcing at } \\
\text { NPD| Customer Life Value }\end{array}$} & $\begin{array}{l}\text { a) } 91 \% \text { of the practices presented a positive relationship with } \\
\text { the success of NPD; }\end{array}$ \\
\hline & $\begin{array}{l}\text { b) } 2 \% \text { of the practices presented a negative relation with NPD, } \\
\text { much in function of the way such practices were being applied } \\
\text { in the companies studied by the authors of the studies (Enkel } \\
\text { et al., 2005; Pesch et al., 2016); }\end{array}$ \\
\hline & $\begin{array}{l}\text { c) } 7 \% \text { of the practices presented variable results in the NPD. It } \\
\text { is important to highlight here the fact that these results, in } \\
\text { general, were presented in publications that proposed to } \\
\text { analyze hypothetical situations (Frankort, 2016; Brem et al., } \\
2017 \text {; Kettunen et al., 2015, Jha et al., 2017; Sobrero, 2000), } \\
\text { with variations in results, both positive and negative, } \\
\text { according to the proposed market situation. Or, cases in which } \\
\text { several practices were evaluated (He et al., 2016), resulting in } \\
\text { a ranking of best practices according to the market situation; }\end{array}$ \\
\hline & $\begin{array}{l}\text { d) These practices have been identified in cases involving } \\
\text { distinct sectors, such as Manufacturing, Automotive, } \\
\text { Biotechnology, and other segments. This issue indicates that, } \\
\text { due to their dispersion and occurrence in different market } \\
\text { segments, they can be characterized as key capabilities to be } \\
\text { focused on and developed, mainly regarding Integration } \\
\text { (Suppliers-Companies) and Strategic Alliances. }\end{array}$ \\
\hline
\end{tabular}

Source(s): Research data

Figure 5. Categorization and findings 
INMR

19,2

NPD practice

NPD practice

Qty

Supplier integration

Open innovation flow

Quality management

Client integration

Product platforms

Several practices

Client and supplier integration

Sustainability

Physical and virtual prototypes

Capturing new opportunities

Design

Outsourcing in NPD

Management tools

Product life cycle management

Innovation supply

Strategic planning

Global NPD team

Portfolio management

Knowledge management

Multidisciplinary teams

Information technology

Product pre-development management

Cost forecast

Enterprise network

Demand forecasting

Project strategy

Management flexibility

Social networks

Market strategy

Management innovation

Information management

Patent analysis

Marketing

Integration of sectors

Open innovation

Customer lifetime value

Interorganizational strategies

Table 1.

Reverse engineering

SPS tools

1 Flexibility of work environment 100

$\begin{array}{llr}1 & \text { Flexibility of work environment } & 1 \\ & \text { Total } & 100\end{array}$

NPD Practices

identified in the articles Source(s): Research data

\begin{tabular}{llll} 
NPD practice & Before 2010 & Before 2015 & After 2015 \\
\hline
\end{tabular}

Table 2.

NPD practices by period
Supplier integration

Strategic alliances

Client integration

Sustainability

Design

Global NPD team

Portfolio management

Management tools

Innovation supply

Information technology

Marketing

Management flexibility

Enterprise network

Cost forecast

Open innovation

Knowledge management

Reverse engineering

Source(s): Research data

3
2
2
1
0
1
1
0
1
1
0
0
1
0
0
0
0

new products, are seen as emerging research practices in line with the evolution of the business environment and should also be the focus of future studies.

4.2 Patterns identified: discussions on integration capability

After the gathering of the 100 most cited and published articles in international journals on

NPD practices, we conducted an analysis to organize their categories concerning the best 
practices that influence NPD. The patterns found present an emerging issue for discussion integration capability - according to the following aspects: (1) the three most cited practices in these articles ( $7 \%$ of the NPD practices account for $30 \%$ of the articles analyzed) are related to integration, (2) the positive relationship between integration practices and successful NPD, as discussed in Section 4.1, (3) occurrence of these integration practices in different research environments, as discussed in Section 4.1 and (4) the distribution of these integration practices over different periods of time (Section 4.1, Table 2).

The findings suggest and support the proposal of integration with suppliers, customers and strategic alliances as a set of structural and transversal best practices for the development of new products. It is important, however, to distinguish integration and from the capability for integration. For Johnson and Fillipini (2013), the application of integration practices, whether internal (where the company seeks to integrate its areas and processes of marketing and sales, product/engineering development and operations) or external (such as connectivity with customers and suppliers during the development) is essential to NPD success, considering the necessary multidisciplinarity. However, the authors point out that the adoption of integration practices does not always lead to better performance (for example, too much functional collaboration can have a nonbeneficial effect due to the specialization of and focus on internal activities); in order to understand the reason that lies behind such argument, the authors introduce the concept of integration capabilities as mediators between NPD integration and performance practices. In line with Winter (2003), capabilities in essence are distinguished from operational and short-term processes (considered ordinary capabilities) and are considered dynamic higher-order capabilities, which they allow the organization to expand, modify or create ordinary capacities, reconfiguring itself. Thus, in accordance with such concept, copyable integration practices are not the ones that become the source of success for NPD, but how they are composed to become real organizational capabilities. This implies, in practical terms, the company's ability to dynamically generate value and change in its relationship with suppliers and customers (Tzokas, Kim, Akbar, \& AlDajani, 2015). To sustain and reconfigure the operational procedures necessary to maintain these relationships over time as environmental changes occur is a dynamic process, considering that capabilities are associated with the ability to adapt and change. NPD managers face up to the challenge of the duality exploring core capabilities versus exploring organizational core rigidities: when the latter are higher, the capacity for change is compromised and consequently the performance of NPD (Leonard-Barton, 1992). Generally, a level of integration can exist between supplier and customer, but in a rigid way with no room for adaptations. A valid example is vertical integration contracts. In other words, there is an integration practice but not necessarily a dynamic integration capacity. If some changes in the environment require an adaptation in the way this integration takes place (contracts, communication flows, informational integration, among others), integration will distinguish from integration capability. Thus, the capability goes beyond the procedure itself as it also incorporates the capacity for change, especially in response to turbulent environments.

Thus, the integration capability is a central issue for new product development. This perspective demonstrates that when an organization establishes a higher and better level of integration in the horizontal (suppliers and customers) and vertical (strategic alliances) dimension, there are better chances to enhance NPD, and consequently a more effective product launch, in addition to risk sharing in alliances (Sivadas \& Dwyer, 2000). A possible explanation for the association between integration capacity and NPD success is that product development should be the creation of new knowledge at the organizational level; it deals with the boundaries where knowledge is generated and structured differently in distinct organizational functions (Amaya Rivas, Cheng, \& Yang, 2020; Carlile, 2002). Thus, in order to integrate it, it is necessary to understand that this differentiation exists. Considering the necessary combination of knowledge in phases of the entire process, whether marketing, technological, management, 
INMR

19,2

114

tacit or explicit knowledge, the capability for integration becomes decisive to generate the necessary conditions to accelerate or create barriers to the process. It occurs due to the involvement of companies, suppliers, customers and alliances, such as universities and research and development centers, in building and combining knowledge in the NPD process.

The ability to integrate is also fundamental since it enables the complementation of competencies through the combination of external and internal knowledge (Hoang \& Rothaermel, 2011) and through resources and assets that the company lacks internally through the interface with external knowledge, which enables the feasibility of new development projects (Ferraris, Devalle, Ciampi, \& Couturier, 2019) and promotes competitive advantage (Rothermel, 2001). Thus, many of the successful NPD practices cited in the literature can be built based on integration, where competence is acquired through a synergy of efforts.

Another emerging practice to be discussed herein is co-creation. Considering the importance of integration capability, it enables the co-creation capability in the NPD context at its different stages (Hoyer, Chandy, Dorotic, Krafft, \& Singh, 2010). Although co-creation is not directly observed among the most cited articles identified, there is a growing interest in the subject concerning NPD, as shown in Figure 6, which can be explained by the fact that it is a more recent theme in the area.

According to the co-creation concept, it is necessary to differentiate the role of co-producer from co-creator; while the first refers to the involvement in the productive process of a good or service, the second involves more active participation in this value chain (Chathoth, Altinay, Harrington, Okumus, \& Chan, 2013; Etgar, 2008). The integration with customers, which enables the exchange of information regarding their specific needs in the customization of products, can lead to better chances of success in product development; in addition, customers must actively participate in the creation process and not only in satisfaction surveys. This approach expands the ability to identify demands and validates a value proposition, if the company has the necessary absorptive capacity for such (Morgan, Obal, \& Anokhin, 2018). Likewise, even if integration enables the co-production or higher involvement, it is necessary to distinguish this continuum. From a different perspective, to meet this demand, the capability for integration (involving co-creation with suppliers in purchase or distribution channels) is critical to combine new knowledge. In this case, specifications, materials, delivery capacity and aspects inherent to product development must be handled more efficiently and involved in different stages of NPD, especially in turbulent scenarios (Lawson, Krause, \& Potter, 2015; Luzzini, Amann, Caniato, Essig, \& Ronchi, 2015; Petersen, Handfield, \& Ragatz, 2005). From a company perspective, it requires attitude to overcome barriers to information sharing, with positive effects for NPD (Ragatz, Handfield, \& Scannell, 1997). Thus, higher capability for simultaneous integration between suppliers and customers becomes a structuring practice for the success of NPDs and starts to enable co-creation capabilities. This relationship with co-creation at the horizontal level is in line with the findings of Moon, Johnson, Mariadoss, and Cullen (2018), in which the involvement of suppliers and customers in the co-creation layout is positive for NPD.

At the vertical level, integration and co-creation can be observed in strategic alliances. The NPD process involves phases such as identifying opportunities (generating ideas and identifying market needs), design and development (positioning, segmentation, engineering and market studies), testing (product and pre-launch), market introduction and life cycle management. Therefore, these alliances can also be very relevant to the success of NPD since there is evidence of the positive effects of coopetition on NPD (Bouncken, Fredrich, Ritala, \& Kraus, 2018; Estrada, Faems, \& de Faria, 2016; Gerwin, 2004; Gerwin \& Ferris, 2004). For example, the ability to integrate a partner to a company located in different time zones can accelerate the development of the project for the market as it enables teams to work uninterruptedly in the development process. Likewise, in the design and development phases, 


\begin{tabular}{|c|c|}
\hline Author & Contributions for Cocreation and NPD \\
\hline Schweitzer et al. (2020) & Point out co-creation as a research agenda for the NPD area \\
\hline Thakur, Wernz et al. (2020) & Transaction costs from different sources for NPD, involving co-creation \\
\hline Wang et al. (2020) & Configuration of co-creation processes with clients in NPD \\
\hline Chang (2019) & Positive effects of customer participation at different stages of NPD \\
\hline Mikkelsen and Johnsen (2019) & Positive effects of supplier involvement in turbulent environments \\
\hline Zahay et al. (2018) & Positive crowdsourcing effects on NPD \\
\hline Morgan et al. (2018) & Positive client co-creation relations at NPD \\
\hline Um and $\operatorname{Kim}(2018)$ & Collaboration and opportunism as mediators of NPD's performance \\
\hline Thomas and Obal (2018) & Type of knowledge shared and impact on NPD \\
\hline Wutke et al. (2018) & Positive effects of co-creating suppliers on NPD \\
\hline Yan and Azadegan (2017) & $\begin{array}{l}\text { Different co-creation strategies are required, depending on whether there is a greater } \\
\text { emphasis on product novelty or short-term financial performance. }\end{array}$ \\
\hline Ettlie et al. (2017) & Integration between trust, IT and NPD \\
\hline Bashir et al. (2017) & Social Media Application for Co-creation at NPD \\
\hline Gonzalez-Zapatero et al. (2017) & Integration and Co-Creation of Purchasing and Marketing for NPD \\
\hline Tolonen et al. (2017) & Co-creation in Supply Chain and NPD \\
\hline Lu et al. (2017) & Open Innovation and NPD \\
\hline Chang and Taylor (2016) & $\begin{array}{l}\text { Meta-analysis of converging to the positive influence of consumer participation in NPD } \\
\text { processes, with positive effects identified in turbulent environments }\end{array}$ \\
\hline Varleyne (2015) & Consumer connectivity is positive in co-creation processes, requiring ICT resources \\
\hline Campbell and Cooper (2002) & $\begin{array}{l}\text { Customer partnering at NPD may be more important for a long-term strategic } \\
\text { perspective, targeting more concentrated markets, or for long-term learning, since } \\
\text { partnership projects have a greater advantage of a new product, than for short-term } \\
\text { scenarios }\end{array}$ \\
\hline Fuchs and Scheirer (2011) & $\begin{array}{l}\text { Customer empowerment is also identified as positive for the NDP enabling participation } \\
\text { and motivation to co-create }\end{array}$ \\
\hline
\end{tabular}

Cross-cutting best practices for NPD

115

Source(s): Research data

the collaboration and combination of resources of these organizations via co-creation is also critical to accelerating NPD; it occurs through the integration of creative and technological human resources. At a different level, the ability to integrate and co-create with universities and research centers allows new product, process and system technologies that also enable higher value generation for the new products developed. Accordingly, the need to ensure that there is a capacity for change on integrations established with customers, suppliers and strategic alliances emerges, which enables the co-creation capability.

\subsection{Relationships between integration, co-creation and ICT's}

Since the capability for integration is dynamic, that is, it relates to adaptation, it is understood that the capability for change is directly related to the identification, absorption and interpretation of new information, and especially to feedback. If there are no conditions to perceive signals from the environment, i.e. to capture these signals through data, convert them into information and create knowledge and meaning, the capability for change and response is compromised. In the context of NPD, this relationship can occur through the observation of market trends, consumer behavior, technological trends and trends in competitors' moves. Co-creation capability anticipates the information that is generated for the company and can be exponentially expanded in uses of crowdsourcing approaches for NPD (Poetz \& Schreier, 2012), or even design thinking. That is, instead of using intermediaries between the company and the customer, such as research institutes through the generation of market intelligence to identify customer needs, the co-creation capability accelerates this generation of information directly to the company, accelerating the NPD process, and consequently the response time to changes. Still, co-creation, insofar as it assumes an interaction, also presumes a relationship of trust based on exchanges and participation in the construction throughout the process. This way, even though the integration capability enables co-creation practices, co-creation also supports the strengthening of the integration. 
INMR

19,2

116

Regarding the relationship between customers, company, suppliers and alliances, the capability for change associated with NPD depends on all the information that circulates throughout the development flow: level of product acceptance, product levels, test marketing, technological stability, among others. Through product validation information, identified throughout the process, changes can be processed, analyzed, decided and implemented. The disorganization of this flow of information and communication leads to critical failures in the development of new products. Therefore, at this point, there is an understanding that the capabilities of applying information and communications technology (ICT) to the integration processes with suppliers, customers, and alliances - aiming at co-creation - become structural elements to build the capabilities for change, especially in contexts of market pull or technology push. The positive benefits of ICT on NPD occurs in the fields of information flow, transparency, organization, collaboration, language and connectivity (see Figure 7).

Hence, Raymond, Uwizeyemungu, Fabi, and St-Pierre (2018) and Mauerhoefer, Strese, and Brettel (2017), when analyzing the impact of ICTs on the performance of NPD, identified that the impacts are positive when constituted as capabilities. This perspective means that information systems do not simply standardize routines creating limitations. They enable the ability to change based on the promotion of connectivity and anticipation, in addition to the involvement with senior management. Thus, the pattern identified in the publications leads to an understanding: among so many managerial decisions for NPD success, considering the number of factors already investigated in literature, there is a need to prioritize the construction of the integration and co-creation capabilities, which are enabled by ICTs. Thus, as far as better integration with suppliers, alliances and customers is promoted, a more structured and cohesive flow of information and communication shall occur, which brings positive impacts for NPD. Especially in the context of innovative product and service development, where stronger multidisciplinarity and a network of actors are needed, such perspective is required. Moreover, the construction of an organizational memory is critical for creativity and NPD (Moorman \& Miner, 1997). Considering that the

\begin{tabular}{|c|c|}
\hline $\begin{array}{l}\text { NPD and ICT } \\
\text { relationship }\end{array}$ & Discussion \\
\hline $\begin{array}{c}\text { Information } \\
\text { Flow }\end{array}$ & $\begin{array}{l}\text { The Integration Capacity can be understood as also involving the ability to integrate the flow of } \\
\text { information, given the quantity and quality of information that circulates between suppliers, customers, } \\
\text { and alliances in NPD processes, investments in ICT enable the organization to assign meaning to the entire } \\
\text { data chain generated throughout the process together with the communication of the multifunctional } \\
\text { parties involved (Tai, 2017). For Zhan et al. (2017), NPD is a matter of big data, and the ability to deal } \\
\text { with internal and external knowledge big data is positive for innovation success, as also observed by Tan } \\
\text { and Zhan (2017). }\end{array}$ \\
\hline $\begin{array}{l}\text { Transparency, } \\
\text { Organization } \\
\quad \text { and } \\
\text { Collaboration }\end{array}$ & $\begin{array}{l}\text { From the transparency of information, the perception of integration between the parties involved is built. } \\
\text { The collaboration between these actors throughout the development of a new product can be influenced } \\
\text { by their level of exchange of useful information inherent to the specific stages of NPD. It can be observed } \\
\text { that in scenarios of disorganization of information and communication flows throughout the NPD where } \\
\text { there is a higher level of parties involved, there are impacts on the success of the project. }\end{array}$ \\
\hline Language & $\begin{array}{l}\text { Integration, therefore, depends on collaboration, which also involves the construction of a common } \\
\text { language in the exchange of information. In this aspect, ICTs can also help in the uniformization of this } \\
\text { language, from dictionaries, libraries associated with the NPD, and metadata of parameters, building } \\
\text { greater understanding and systematization of knowledge, as well as communication between these various } \\
\text { parties in the NPD process. A critical point concerning the development of new products concerns the } \\
\text { decision making information about the progress of the project, whose ICTs can support in its registration, } \\
\text { evaluation, and communication process. }\end{array}$ \\
\hline Connectivity & $\begin{array}{l}\text { Consequently, ICTs, through their interface, enable connectivity from increasingly agile co-creation } \\
\text { mechanisms, whether, on the client's side, suppliers, or strategic alliances, also involving Universities, as } \\
\text { the flow of information of demands and possible solutions begins to streamline the processes of identifying } \\
\text { opportunities between client and company. With the convergence of information between the requirements } \\
\text { between company and suppliers, between the combination of design and technology elements with } \\
\text { strategic alliances, ICT's enable a co-creation capacity, which therefore enables greater Integration } \\
\text { Capacity, which is central to the Development of New Products. }\end{array}$ \\
\hline
\end{tabular}

Figure 7. Relationship between NPD and ICT
Source(s): Developed by the authors 
development of a new product occurs through the generation of new knowledge, involving scientific and technological expertise, the processes must enable a better knowledge combination based on the generation of data and analysis. Thus, by merging the findings of our research on integration capability with the emerging discussions about co-creation and ICTs, it was possible for us to establish a few relationships. These aspects, therefore, can lead to higher success in NPD and its capability for innovation (see Figure 8), thus constituting basis or structuring transversal factors. These basic or structuring factors are combined with the other practices identified in the literature, which are more or less dependent on the segment in which the business operates, size and level of internationalization.

This framework indicates the networking capability (connecting with external partners) and networking ability (the ability of NPD managers to work with stakeholders outside the company), which are both positive for DNP (Mu, Thomas, Peng, \& Di Benedetto, 2017). Studies point out curvilinear effects between the number of partners and performance (Mishra, Chandrasekaran, \& Maccormack, 2015), which demands new skills to deepen the quality of partnerships to suppress this effect (Kurpjuweit, Reinerth, \& Wagner, 2018). This type of model may be appropriate in turbulent scenarios, where companies have limited resources to invest in all internal DNP practices, i.e. when companies pursue complementary assets.

\section{Final remarks and suggestions for future studies}

Our study presented a research strategy based on the systematic review method, in which the 100 most cited articles published in international journals were analyzed, identifying the categories of practices associated with NPD. One pattern found is that, in ours sample, three categories ( $7 \%$ of the total) represent $30 \%$ of the articles identified. The construction of our framework led to the conclusion that the practice of integration is one of the structural and cross-cutting best practices for NPD. Thus, this paper discusses the importance of integration capacity for NPD, which differs from integration per se and, according to Johnson and Fillipini (2013), would become increasingly necessary for organizations to overcome NPD expectations in terms of product performance and time. However, as the integration capability becomes a critical success factor, new capacities are increasingly required, especially in turbulent environments, where the capabilities for change and knowledge sharing in NPD supported by ICTs (Gao \& Bernard, 2018) are increasingly necessary. (Pavlou \& El Sawy, 2006, 2010).

Such results indicate, therefore, that the improvement of NPD performance of an organization must essentially rely on the search of an integration capability and, consequently, of collaboration at the vertical and horizontal level, involving suppliers,

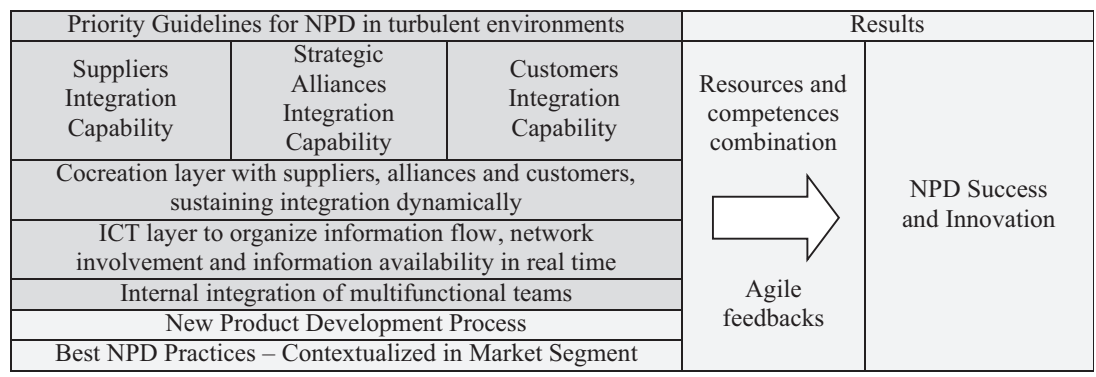

Figure 8. Cross-cutting best practices for NPD success

Source(s): Research data 
INMR

19,2

118

customers and alliances, such as universities and research institutes. Especially in the current context, in which advantages are increasingly built based on innovation ecosystems, the capacity for integration becomes increasingly essential since it also enables the complementation of competencies and resources for the development of new products. According to this logic, when such integration processes become critical for NPD performance, integration must be created as a dynamic capability - i.e. a capability that enables adaptations to the environment - through co-creation processes, where the active proximity to customers, suppliers and alliances throughout the NPD stages expands the possibility of interaction, building trust and reciprocity, contributes to a greater capacity to build knowledge, validates the value proposal throughout the development and complements skills and resources. However, with the increase in the complexity of actors and information generated throughout the process, investments in ICTs, as a way to ensure agility, flexibility, speed and transfer of information and knowledge, become critical capabilities of organizations pursuing better NPD performance and successful innovations, especially in global environments.

Therefore, our study contributes to literature with the proposition of the theoretical framework in NPD, sustaining the integration capability as a cross-cutting and transversal practice in NPD. This implies integration practices at the vertical and horizontal level, which relates to co-creation processes with the support of ICTs. Further investigations into the effects of these variables can indicate a relevant research agenda in the field. In managerial terms, the results of the systematic review indicate that investments and prioritization in the ability to integrate at the vertical and horizontal level can increase NPD's success rate, even though such factors are not the only ones responsible for this result. Considering the structural and transversal factors mentioned herein, managers could prioritize investments to design, build or improve their NPD model based on such foundations, assessing their integration capability, co-creation capability and assessing which ICT technologies are more suitable to support the NPD process adopted by the company. NPD also involves a human component as it is a process of creating and building knowledge, which requires the recruitment of cognitive skills. Thus, the pattern found in this research contributes to these theoretical and managerial dimensions, which enables the development of future studies based on the model proposed in our study, as well as the development of a maturity model at the integration level for NPD considering its validation.

Although the objective of the study was not to describe the panorama of the area from a systematic review approach, but to identify new patterns through this process, it is possible to consider the sampling chosen a limitation of the study. We suggest, therefore, the expansion of the sample and the incorporation of other databases in future studies. In addition, considering we only chose the "new product development" operator, we suggest for future research to advance our findings by adding complementary operators and to analyze NPD relationships in different segments, given the diversity of practices identified. Future studies are also recommended to analyze the types of integration from a strategic orientation approach, especially in family-controlled companies (De Massis, Frattini, \& Lichtenthaler, 2013; De Massis, Frattini, Kotlar, Petruzzelli, \& Wright, 2016). Moreover, the proposed framework can support both theoretical and managerial agenda regarding NPD and digital transformation.

\section{References}

Amaya Rivas, A., Chen, Y.-C., \& Yang, T.-K. (2020). Entrepreneurial and alliance orientation alignment in new product development. Technological Forecasting and Social Change, Elsevier, 153(C).

Barczak, G., \& Kahn, K.B. (2012). Identifying new product development best practice. Business Horizons, 55(3), 293-305. 
Boehe, D.M., Milan, G.S., \& de Toni, D. (2009). Desempenho do processo de desenvolvimento de novos produtos: o peso relativo de fatores organizacionais, mercadológicos e operacionais. Revista de Administração-RAUSP, 44(3), 250-264.

Bouncken, R.B., Fredrich, V., Ritala, P., \& Kraus, S. (2018). Coopetition in new product development alliances: Advantages and tensions for incremental and radical innovation. British Journal of Management, 29(3), 391-410.

Buyukozkan, G., \& Feyzioglu, A. (2004). A new approach based on soft computing to accelerate the selection of new product ides. Computers in Industry, 54, 151-167.

Carlile, P.R. (2002). A pragmatic view of knowledge and boundaries: Boundary objects in new product development. Organization Science, 13(4).

Carrizo-Moreira, A., \& Leonidivna, K.H. (2014). Uma revisão interpretativa sobre o desenvolvimento de novos produtos. Cuadernos de Administración, 27(49), 155-182.

Chao, Y., \& Chen-Hao, L. (2015). How innovation capability and organizational integration mediate market orientation and NPD success. Proceedings of the International Conference on Information Management and Evaluation, 29-33.

Chathoth, P., Altinay, L., Harrington, R.J., Okumus, F., \& Chan, E.S.W. (2013). Co-production versus cocreation: A process based continuum in the hotel service context. International Journal of Hospitality Management, 32(1), 11-20, doi: 10.1016/j.ijhm.2012.03.009.

Chen, J., Damanpour, F., \& Reilly, R.R. (2010). Understanding antecedents of new product development speed: A meta-analysis. Journal of Operations Management, 28(1), 17-33, doi: 10.1016/j.jom. 2009.07.001.

Cheng, C., Chen, J.S., \& Tsou, H.T. (2012). Market-creating service innovation: Verification and its associations with new service development and customer involvement. Journal of Services Marketing, 26(6), 444-457.

Cooper, R.G. (2019). The drivers of new-product development. Industrial Marketing Management, 76, $36-47$.

Cooper, R.G., \& Kleinschmidt, E.J. (1995). Benchmarking the firm's critical success factors in new product development. The Journal of Product Innovation Management, 12(5), 374-391.

Costa, P., Porto, G., \& Plonski, G. (2010). Gestão da cooperação empresa-universidade nas multinacionais brasileiras. INMR - Innovation and Management Review, 7(3), 150-173.

Crossan, M.M., \& Apaydin, M. (2010). A multi-dimensional framework of organizational innovation: A systematic review of the literature. Journal of Management Studies, 47(6), 1154-1191.

De Massis, A., Frattini, F., \& Lichtenthaler, U. (2013). Research on technological innovation in family firms: Present debates and future directions. Family Business Review, 26(1), 10-31.

De Massis, A., Frattini, F., Kotlar, J., Petruzzelli, A.M., \& Wright, M. (2016). Innovation through tradition: Lessons from innovative family businesses and directions for future research. Academy of Management Perspectives, 30(1), 93-116.

De Toni, D., Milan, G.S., \& Reginato, C.E.R. (2011). Fatores críticos para o sucesso no desempenho de novos produtos: Um estudo aplicado ao setor moveleiro da serra gaúcha. Gestão and Produção., 18(3), 587-602.

Estrada, I., Faems, D., \& de Faria, P. (2016). Coopetition and product innovation performance: The role of internal knowledge sharing mechanisms and formal knowledge protection mechanisms. Industrial Marketing Management, 53, 56-65.

Etgar, M. (2008). A descriptive model of the consumer Co-production process. Journal of the Academy of Marketing Science, 36(1), 97-108.

Evanschitzky, H., Eisend, M., Calantone, R.J., \& Jiang, Y. (2012). Success factors of product innovation: An updated meta-analysis. Journal of Product Innovation Management, 29, 21-37.

Falagas, M., Pitsouni, E., Malietzis, G., \& Pappas, G. (2008). Comparison of PubMed, Scopus, Web of science, and google scholar: Strengths and weaknesses. FASEB Journal, Feb, 22(2), 338-4. 
INMR

19,2

Ferraris, A., Devalle, A., Ciampi, F., \& Couturier, J. (2019). Are global R\&D partnerships enough to increase a company's innovation performance? The role of search and integrative capacities. Technological Forecasting and Social Change, Elsevier, 149(C).

Flynn, B., Huo, B., \& Zhao, X. (2010). The impact of supply chain integration on performance: A contingency and configuration approach. Journal of Operations Management, 28, 58-71.

Gao, J., \& Bernard, A. (2018). An overview of knowledge sharing in new product development. International Journal of Advanced Manufacturing Technology, 94(5-8), 1545-1550.

Gerwin, D. (2004). Coordinating new product development in strategic alliances. Academy of Management Review, 29(2), 241-257.

Gerwin, D., \& Ferris, J.S. (2004). Organizing new product development projects in strategic alliances. Organization Science, 15(1), 22-37+130.

Griffin, A. (1997). PDMA research on new product development practices: Updating trends and benchmarking best practices. Journal of Product Innovation Management, 14(6), 429-458.

Gusenbauer, M., \& Haddaway, N. (2020). Which academic search systems are suitable for systematic reviews or meta-analyses? Evaluating retrieval qualities of google scholar, PubMed and 26 other resources. Research Synthesis Methods, 11(2), 181-217.

Haverila, M. (2010). The marketplace variables in successful and unsuccessful NPD projects in technology intensive companies. Journal of Technology Management and Innovation, 5(4), 121-136.

Henard, D., \& Szymanski, D. (2001). Why some new products are more successful than others. Journal of Marketing Research, 38(3), 362-375.

Hoang, H., \& Rothaermel, F.T. (2011). Leveraging internal and external experience: Exploration, exploitation, and R\&D Project performance. Strategic Management Journal, 31(7), 734-758.

Hoyer, W.D., Chandy, R., Dorotic, M., Krafft, M., \& Singh, S.S. (2010). Consumer cocreation in new product development. Journal of Service Research, 13(3), 283-296.

Jia, Q., Kang, L., \& Gao, X. (2016). A design rational knowledge model supporting configuration management in aerospace product development. Proceedings of the European Conference on Knowledge Management, Kidmore End. Academic Conferences International, 405-412.

Johnson, W., \& Fillipini, R. (2013). Integration capabilities as mediator of product development practices-performance. The Journal of Engineering and Technology Management, 30, 95-111.

Koufteros, X.A., Rawski, G.E., \& Rupak, R. (2010). Organizational integration for product development: The effects on glitches, on-time execution of engineering change orders, and market success. Decision Sciences, 41(1), 49-80.

Kurpjuweit, S., Reinerth, D., \& Wagner, S.M. (2018). Supplier Innovation Push: Timing Strategies and Best Practices a number of motivating and moderating factors influence suppliers' decisions to involve customers in the innovation process. Research Technology Management, 61(2), 47-55.

Lawson, B., Krause, D., \& Potter, A. (2015). Improving supplier new product development performance: The role of supplier development. Journal of Product Innovation Management, 32(5), 777-792.

Leonard Barton, D. (1992). Core capabilities and core rigidities: A paradox in managing new product development. Strategic Management Journal, 13(1S), 111-125.

Li, Z., Pehlken, A., Qian, H., \& Hong, Z. (2016). A systematic adaptable platform architecture design methodology for early product development. Journal of Engineering Design, 27(1-3), 93-117.

Luzzini, D., Amann, M., Caniato, F., Essig, M., \& Ronchi, S. (2015). The path of innovation: Purchasing and supplier involvement into new product development. Industrial Marketing Management, 47, 109-120.

Mauerhoefer, T., Strese, S., \& Brettel, M. (2017). The impact of information technology on new product development performance. J Prod Innov Manag, 34, 719-738. 
Meho, L.I., \& Yang, K. (2007). Impact of data sources on citation counts and rankings of LIS faculty: Web of science versus scopus and google scholar. Journal of the American Society for Information Science and Technology, 58(13), 2105-2125.

Mishra, A., Chandrasekaran, A., \& Maccormack, A. (2015). Collaboration in multi-partner R\&D projects: The impact of partnering scale and scope. Journal of Operations Management, 33-34, $1-14$.

Montoya-Weiss, M.M., \& Calantone, R. (1994). Determinants of new product performance: A review and meta-analysis. The Journal of Product Innovation Management, 11(5), 397-417.

Cross-cutting best practices for NPD

Moon, H., Johnson, J.L., Mariadoss, B.J., \& Cullen, J.B. (2018). Supplier and customer involvement in new product development stages: Implications for new product innovation outcomes. International Journal of Innovation and Technology Management, 15(1).

Moorman, C., \& Miner, A.S. (1997). The impact of organizational memory on new product performance and creativity. Journal of Marketing Research, 34(1), 91-106, doi: 10.2307/3152067.

Morgan, T., Obal, M., \& Anokhin, S. (2018). Customer participation and new product performance: Towards the understanding of the mechanisms and key contingencies. Research Policy, 47(2), 498-510.

Mu, J., Thomas, E., Peng, G., \& Di Benedetto, A. (2017). Strategic orientation and new product development performance: The role of networking capability and networking ability. Industrial Marketing Management, 64, 187-201.

O'dwyer, C., \& Cormican, K. (2017). Regulation - do or die: An analysis of factors critical to new product development in a regulatory context. Journal of Technology Management and Innovation, 12(1), 26-38.

Pavlou, P.A., \& El Sawy, O.A. (2006). From IT leveraging competence to competitive advantage in turbulent environments: The case of new product development. Information Systems Research, 17(3), 198-227.

Pavlou, P.A., \& El Sawy, O.A. (2010). The "third hand": IT-enabled competitive advantage in turbulence through improvisational capabilities. Information Systems Research, 21(3), 443-471.

Petersen, K.J., Handfield, R.B., \& Ragatz, G.L. (2005). Supplier integration into new product development: Coordinating product, process and supply chain design. Journal of Operations Management, 23(3-4), 371-388.

Poetz, M.K., \& Schreier, M. (2012). The value of crowdsourcing: Can users really compete with professionals in generating new product ideas?. Journal of Product Innovation Management, 29(2), 245-256.

Ragatz, G.L., Handfield, R.B., \& Scannell, T.V. (1997). Success factors for integrating supplier into new product development. The Journal of Product Innovation Management, 14(3), 190-203, May.

Raymond, L., Uwizeyemungu, S., Fabi, B., \& St-Pierre, J. (2018). IT capabilities for product innovation in SMEs: A configurational approach. Information Technology and Management, 19(1), 75-87.

Rodríguez-Pinto, J., Rodríguez-Escudero, A., \& Gutiérrez-Cilláb, J. (2012). How market entry order mediates the influence of firm resources on new product performance. Journal of Engineering and Technology Management, 29(2), 241-264.

Rothaermel, F.T. (2001). Incumbent's advantage through exploiting complementary assets via interfirm cooperation. Strategic Management Journal, 22(6-7), 687-699.

Sivadas, E., \& Dwyer, F.R. (2000). An examination of organizational factors influencing new product success in internal and alliance-based processes. Journal of Marketing, 64(1), 31-49.

Song, X.M., \& Parry, M.E. (1997). A cross-national comparative study of new product development processes: Japan and the United States. Journal of Marketing, American Marketing Association, 61(2), 1-18, doi: 10.2307/1251827.

Tai, Y.M. (2017). Effects of product lifecycle management systems on new product development performance. Journal of Engineering and Technology Management -JET-M, 46, 67-83. 
INMR

19,2

Tumelero, C., Santos, S.A., \& Plonski, G. (2012). Inovação tecnológica em empresas intensivas na utilização de conhecimentos técnico e científico: Um estudo a partir da visão baseada em recursos (vbr). INMR - Innovation and Management Review, 9(4), 202-220.

Tzokas, N., Kim, Y.A., Akbar, H., \& Al-Dajani, H. (2015). Absorptive capacity and performance: The role of customer relationship and technological capabilities in high-tech SMEs. Industrial Marketing Management, 47, 134-142.

Verona, G. (1999). A resource-based view of product development. The Academy of Management Review, 24(1), 132-142.

Winter, S.G. (2003). Understanding dynamic capabilities. Strategic Management Journal, 24(10), 991-995.

Woschke, T., \& Haase, R. (2016). Enhancing new product development capabilities of small- and medium-sized enterprises through managerial innovations. The Journal of High Technology Management Research, 27(1), 53-64.

Yan, T., \& Azadegan, A. (2017). Comparing inter-organizational new product development strategies: Buy or ally; Supply-chain or non-supply-chain partners?. International Journal of Production Economics, 183, 21-38, available at: https://goo.gl/2U5W2H.

Yang, L.R. (2012). Implementation of project strategy to improve new product development performance. International Journal of Project Management, 30(7), 760-770, available at: https:// goo.g1/q2dtiR.

Zabala-Iturriagagoitia, J.M. (2017). New product development in traditional industries: Decisionmaking revised. Journal of Technology Management and Innovation, 7(1), 31-51.

Zapata, M.L., Berrah, L., \& Tabourot, L. (2020). Is a digital transformation framework enough for manufacturing smart products? The case of small and medium enterprises. Procedia Manufacturing, Elsevier B.V, 42, 70-75, doi: 10.1016/j.promfg.2020.02.024.

Zawislak, P.A., Fracasso, E., \& Tello-Gamarra, J. (2018). Technological intensity and innovation capability in industrial firms. INMR - Innovation and Management Review, 15(2), 189-207.

\section{Corresponding author}

Mateus Panizzon can be contacted at: mpanizzo@ucs.br

Associate Editor: Felipe Borini

For instructions on how to order reprints of this article, please visit our website:

www.emeraldgrouppublishing.com/licensing/reprints.htm

Or contact us for further details: permissions@emeraldinsight.com 